\title{
Seasonal and Spatial Changes of Microorganism Communities in Constructed Wetlands: A Community Level Physiological Profiling Analysis
}

\author{
Florent Chazarenc, ${ }^{1}$ Jacques Brisson, ${ }^{2}$ and Gérard Merlin ${ }^{3}$ \\ ${ }^{1}$ Ecole des Mines de Nantes, GEPEA UMR CNRS 6144, 4, rue Alfred Kastler, B.P. 20722, 44307 Nantes Cedex, France \\ ${ }^{2}$ Institut de Recherche en Biologie Végétale, Université de Montréal, 4101 rue Sherbrooke Est, Montréal QC, Canada H1X $2 B 2$ \\ ${ }^{3}$ Laboratoire Optimisation de la Conception et Ingénierie de l'Environnement, Université de Savoie, \\ Campus Scientifique, 73376 Le Bourget du Lac Cedex, France
}

Correspondence should be addressed to Florent Chazarenc, florent.chazarenc@emn.fr

Received 15 January 2010; Accepted 22 March 2010

Academic Editor: Yves Andrès

Copyright ( $\odot 2010$ Florent Chazarenc et al. This is an open access article distributed under the Creative Commons Attribution License, which permits unrestricted use, distribution, and reproduction in any medium, provided the original work is properly cited.

In constructed wetlands, microorganisms associated with plants are assumed to play a major role. A one-year survey was conducted in five vertical flow constructed wetland systems that had been operating from 2 months to 8 years in small French villages (100500 People Equivalent) to provide a better understanding of microbiological activity. The objective of our study was to highlight the most important factor generating variability between microorganisms communities compared to treatment performances. Results of community level physiological profiling using Biolog Ecoplates were analyzed using principal component analysis. The greatest microbial activity was observed in the oldest wetland during summer. Profiles of fed and rest bed were differentiated by the nature of the main carbon source metabolized. Whereas carbohydrates and carboxylic acids appeared to be better assimilated with fed beds, it seemed that phosphate compounds as well as amines allowed better growth in the plates inoculated with samples of rest beds. In all fed beds, the most important parameters affecting the diversity were the season and the age of the wetlands. There were only slight profile differences between surface and subsurface samples and between the first and second stage samples.

\section{Introduction}

In constructed wetlands (CWs), it is widely recognized that microorganisms associated with macrophytes play a major role in pollutant removal. Over the last ten years a greater focus has been put on understanding microorganisms diversity and spatial distribution, on characterizing bacterial communities, or on monitoring microbial biomass. A large number of biochemical tools were successfully adapted to monitor microorganisms in CWs, such as epifluorescence, enzymatic activities, protein concentration, flow cytometry, fish probes, PCR, and DGGE [1-6].

In vertical flow constructed wetlands (VFCWs), pollutant removal efficiency (especially TKN removal) can be affected by several factors including season, CW age, and feeding mode (batch loads, periods of rest, etc.) Our study aimed at verifying whether treatment performance was linked or not to microbial diversity by applying the community-level physiological profiles (CLPPs) method using Biolog EcoPlate for constructed wetlands microorganism communities. The CLPP method using microtiterplates with multiple sole-carbon sources has become a popular tool for the comparison of microbial communities with respect to their functional potential. CLPP was successfully adapted to the study of complex communities [7]. This method was shown to enable rapid assessment of variation in community structure in biological water treatment systems such as mixed liquor $[8,9]$ or biofilters $[10,11]$.

We analysed microbial diversity in five VFCWs designed to treat raw wastewater. We inoculated a total of 46 plates during two sampling campaigns. The first campaign (25 plates) was realized in February, April, June, and October 


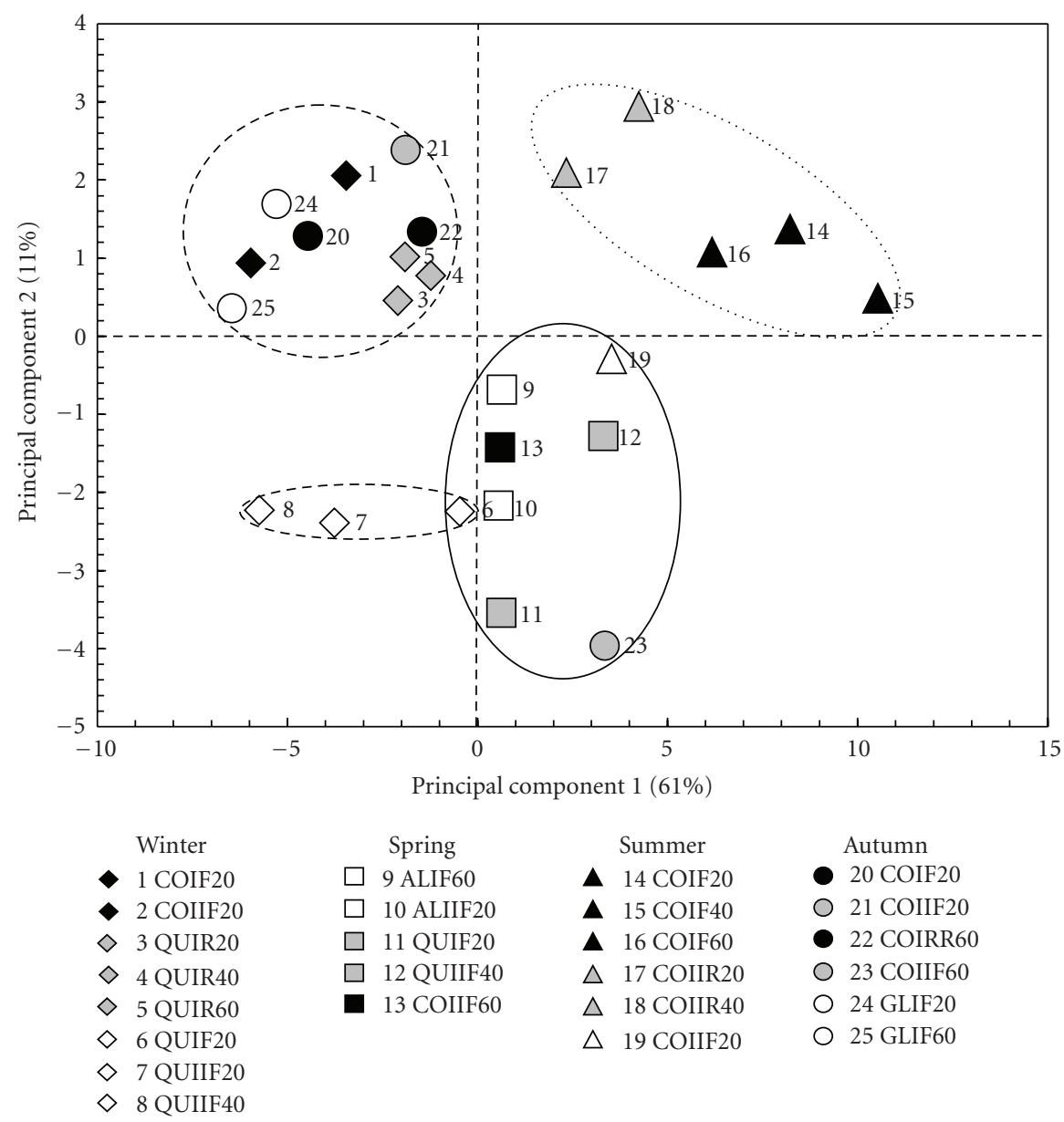

FIgURE 1: PCA of Biolog data of the first sampling campaign. A code identifies each sample: the first two letters refer to the CW name, followed by I for first stage and II for the second; we referred to the depth as 20 for 0-20 cm, 40 for 20-40, cm and 60 for 40-60; the feeding mode was expressed as $\mathrm{F}$ for bed fed for 3 days, $\mathrm{R}$ for bed in rest for 3 days, and RR for bed in rest for 8 to10 days. For example, COIF20RR refers to Colomieu, stage I, $0-20 \mathrm{~cm}$ layer, in rest for 10 days.

2002 in 5 different sites and enabled to highlight season influence on bacteria community profile. The second campaign (21 plates) was performed in November 2003 in two sites to determine the vertical distribution of microbial activity in relation to CW age and feeding mode (fed and rest rotation).

\section{Material and Methods}

2.1. Wetlands Systems. The studied two-stage VFCWs, constructed by the Société d'Ingénieries Nature et Techniques, were designed to treat raw wastewater of small communities in the Rhone-Alpes region of France (Table 1).

Each stage was made of two to four beds fed according to 5-7 days rotation. Beds were $0.7 \mathrm{~m}$. deep and planted with Phragmites australis. Average treatment performances observed during the two campaigns for the first stage of all VFCWs except Evieu are available in Table 2.

2.2. Sampling, Biofilm Solution Extraction, and Biolog Methods. For the first campaign, samples were taken at Colomieu,
Glandieu, Allèves, and Queige at four different dates, 2002 (March, April, June, October). For the second campaign, samples were taken at Colomieu and Evieu, in November 2003. A $60 \mathrm{~cm}$ long core, divided in three $20 \mathrm{~cm}$ sections, was taken at $50 \mathrm{~cm}$ of an inlet pipe. Between 2 and 15 grams of cores were first washed with a phosphate buffer solution $\left(\mathrm{K}_{2} \mathrm{HPO}_{4}, 9.3 \mathrm{~g} \mathrm{~L}^{-1} ; \mathrm{KH}_{2} \mathrm{PO}_{4} 1.8 \mathrm{~g} \mathrm{~L}^{-1} ; \mathrm{pH}=7.2\right)$ to separate gravel and obtain a final solution concentration having $2 \%$ $\mathrm{w} / \mathrm{w}$ of extracted matter and was screened on a $5 \mathrm{~mm}$ filter. This method was effective in normalising the cell number density in the final inoculum for the Biolog EcoPlate. Carbon sources utilization pattern was realized using Biolog EcoPlate (Hayward, CA, USA). Each plate contains 31 of the most useful carbon sources for soil community analysis $[12,13]$. Carbon sources are preloaded and dried into 96 wells (Figure 4). Tetrazolium Violet is used as a redox dye to indicate carbon sources use.

The extraction solution was diluted 20 times using phosphate buffer and vortexed for 10 minutes. Finally $150 \mu \mathrm{L}$ aliquots of supernatant were added in each well. After injection, EcoPlate was incubated at $20^{\circ} \mathrm{C}$ in obscurity for 


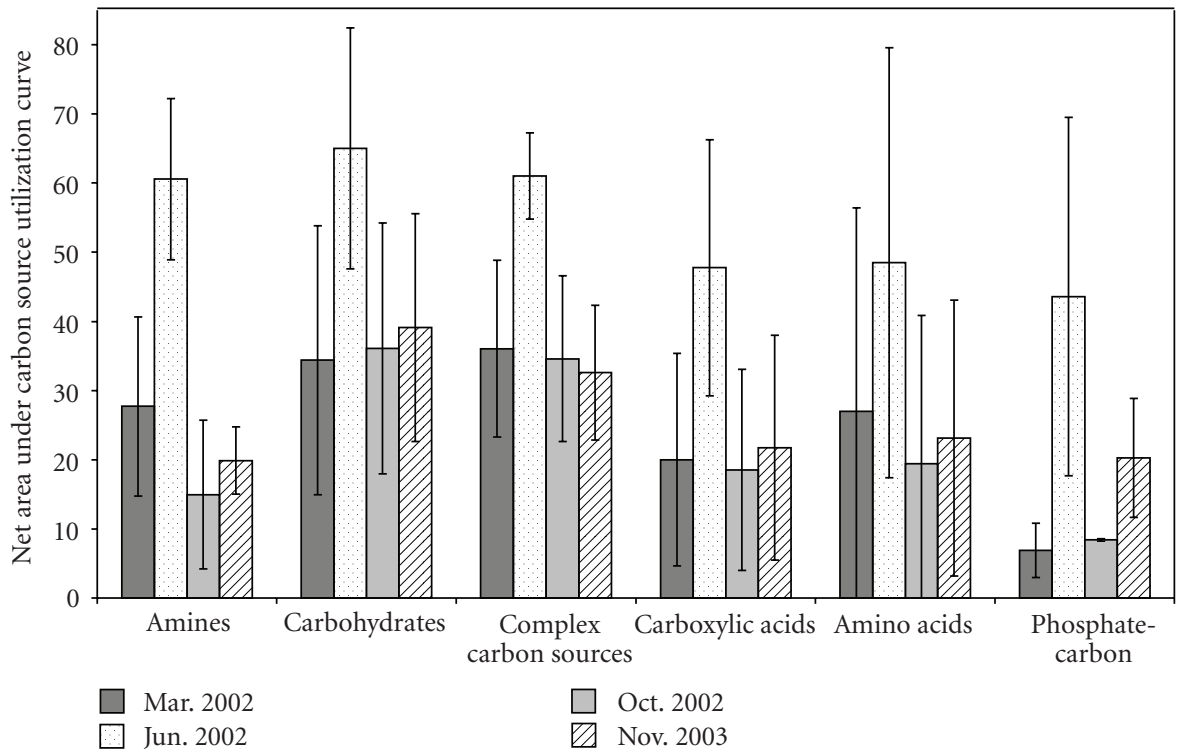

FIGURE 2: Seasonal metabolic response of samples taken in surface of the fed bed, first stage of Colomieu.

TABLE 1: VFCWs characteristics.

\begin{tabular}{|c|c|c|c|c|c|c|}
\hline & Units & Glandieu & Queige & Allèves & Evieu & Colomieu \\
\hline People equivalent & $\mathrm{Pe}$ & 250 & 500 & 250 & $100^{*}$ & 200 \\
\hline First stage area & $\mathrm{m}^{2}$ & 233 & 850 & 360 & - & 300 \\
\hline Second stage area & $\mathrm{m}^{2}$ & 164 & 750 & 230 & - & 225 \\
\hline Initial organic load & $\mathrm{g} \mathrm{BOD}_{5} \mathrm{~m}^{-2} \mathrm{~d}^{-1}$ & 64 & 32 & - & - & 48 \\
\hline Starting date & year & 1999 & 1998 & 1999 & 2003 & 1993 \\
\hline
\end{tabular}

* Evieu was only connected to 30 Pe for almost 3 months during the sampling campaign (November 2003).

at least 72 hours, during which coloration development was measured every 12 hours using a Vmax microplate reader (Molecular Device, Sunnyvale, CA, USA). Results (31 curves/sample) were analysed by curve integration and principal component analysis (PCA) according to Guckert et al. [14] and Kaiser et al. [9]. Since the inoculum density was controlled, data were not normalized by average area on each plate thus giving an indication of the global activity. Data were also compared using grouping of carbon sources. To simplify direct comparison, 6 main categories were chosen: amines, carbohydrates, complex carbon sources, carboxylic acids, amino acids, and phosphate-carbon (Figure 4).

\section{Results and Discussion}

3.1. Carbon Source Utilization. Microbial communities sampled in CWs were generally able to use all of the 31 carbon sources. The most important growths were observed on L-asparagine, L-serine, lactose, mannitol, acetyl glucosamine, glycogen, and cellobiose sources. As expected, elementary sugars or polymers such as glycogen were greatly metabolised, most probably in Kreb's cycle by oxidative phosphorylation. Complex carbon source and carbohydrates provided the best growth, most probably because they are the more energetic compounds. The smallest microbial growths were reported on carbon sources containing aromatic cycle.

3.2. Sampling Campaign 1. Principal component 1 accounted for $61 \%$ of total variability and was mainly associated to carbon source B1, D2, and E2 (Figure 1). Principal component 2 accounted for $11 \%$ of total variability and was mainly associated with B4, C4, F4, and H4 (amino acids). There was little influence of sampling depth and CW age, with Biolog ecoplate profiles being mainly differentiated according to season. Samples taken in warm periods (with bed having full active macrophytes) had more positive score value for the first principal component than samples taken in winter or autumn (Figure 1). Less of the variability was explained by the second principal component differentiating between age of CW (all profiles of Queige and Allèves) and most probably spring profiles compared to the others. Similarities between three distinct groups were drawn with summer profiles in dotted line, spring profiles in indented line, and winter and autumn profiles in full line (Figure 1). This pattern could be linked to a decrease in activity of several bacteria species under cold conditions. Sludge accumulation in the first stages in winter [15], by limiting infiltration rate and oxygen renewal, may also affect microbial communities environment and redox. TKN 
TABLE 2: Average performances (mass removal in \%) observed in the first stage of the different VFCWs (adapted from Chazarenc and Merlin, $[4])$.

\begin{tabular}{lcccccc}
\hline \multirow{2}{*}{ Name } & \multicolumn{3}{c}{ Spring-Summer (average) } & \multicolumn{3}{c}{ Autumn-winter (average) } \\
& TSS & COD & N-TKN & TSS & COD & N-TKN \\
\hline Allèves & $95.2 \pm 5.5$ & $92.3 \pm 4.5$ & $84.2 \pm 12.4$ & $95^{*}$ & $83.9^{*}$ & $76^{*}$ \\
Colomieu & $96.6 \pm 4.5$ & $93,4 \pm 6,4$ & $98.4 \pm 0.6$ & $96.1 \pm 2.2$ & $92.3 \pm 4.2$ & $76.7 \pm 18.5$ \\
Glandieu & $99.6^{*}$ & $98.7^{*}$ & $93.3^{*}$ & $98.5^{*}$ & $95.7^{*}$ & - \\
Queige & $92.5 \pm 6.9$ & $91.0 \pm 9.4$ & $77.7 \pm 26.0$ & $90.1 \pm 8.1$ & $83.0 \pm 7.9$ & $38.3 \pm 14.3$ \\
\hline
\end{tabular}

$*$ only one measurement available.

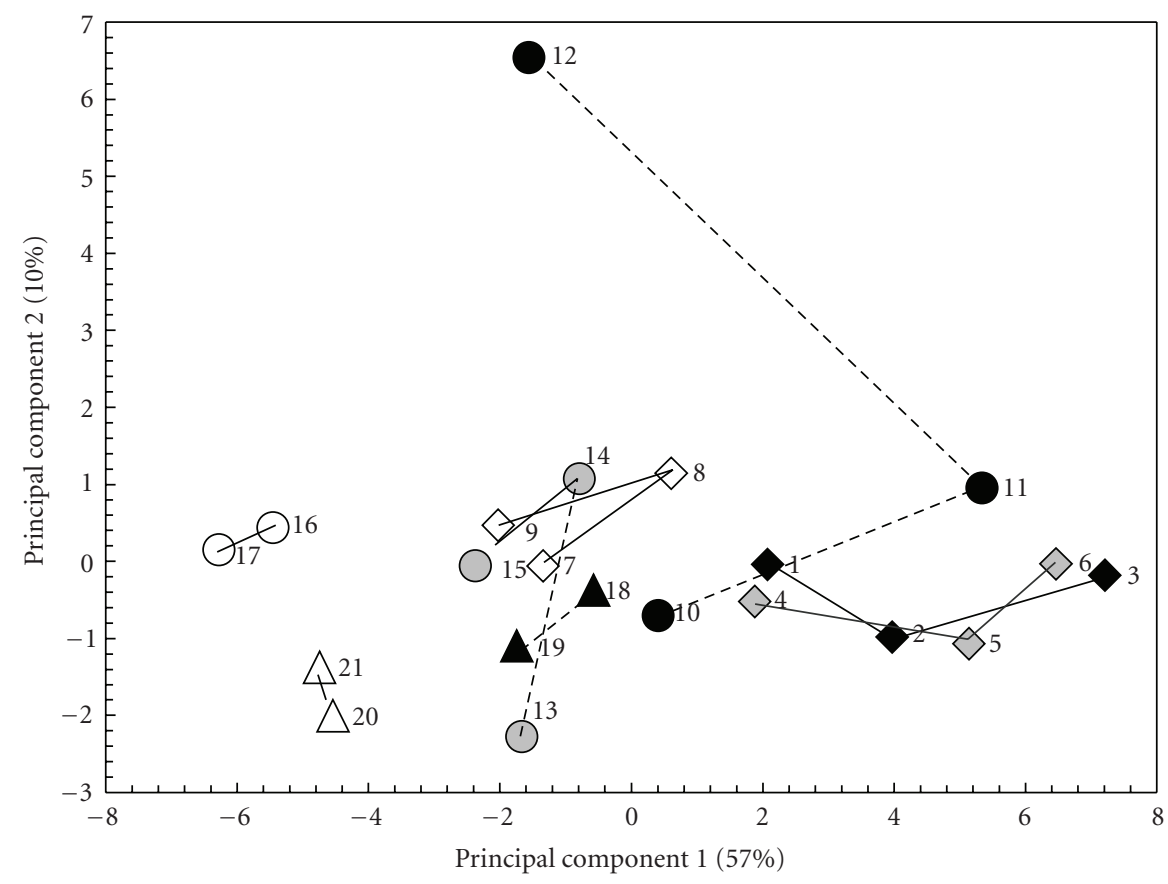

$\begin{array}{lc}\text { CO stage } 1 & \text { CO stage } 2 \\ \bullet 1 \text { COIF20 } & \text { 10 COIIF20 } \\ \text { 2 COIF40 } & \text { 11 COIIF40 } \\ \bullet 3 \text { COIF60 } & \text { C } 12 \text { COIIF60 } \\ \diamond 4 \text { COIR20 } & \bigcirc 13 \text { COIIR20 } \\ \diamond 5 \text { COIR40 } & \bigcirc 14 \text { COIIR40 } \\ \diamond 6 \text { COIR60 } & \bigcirc 15 \text { COIIR60 } \\ \diamond 7 \text { COIRR20 } & \bigcirc 16 \text { COIIRR40 } \\ \diamond 8 \text { COIRR40 } & \bigcirc 17 \text { COIIRR60 } \\ \diamond 9 \text { COIRR60 } & \end{array}$

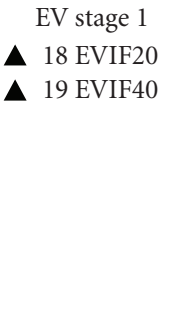

EV stage 2

$\triangle 21$ EVIIF20

$\triangle 22$ EVIIF40

Figure 3: Ordination produced from PCA analysis of Biolog profile obtained during the second campaign. Samples connected with lines represent sampling from the same bed at different depths; full line: Colomieu stage 1; indented line: Colomieu stage 2; dotted line: Evieu. See legend in Figure 2 for sample codes.

removal efficiency decreased from $78 \%$ in summer to $38 \%$ in winter 2002 in Queige and from 98\% to 77\% in Colomieu (Table 2). To some extent, the spring group (full line in Figure 2) represented a transition between little diversified profiles (winter) and summer profiles.

Seasonal variations of bacterial community response in the upper layer of the fed bed in Colomieu illustrate well the seasonal changes observed in all samples (Figure 2). Net activities follow season temperature, with a maximum in June and lower values in late winter and autumn.
3.3. Sampling Campaign 2. Figure 3 shows PCA results obtained when comparing all profiles from the second sampling campaign. Principal component 1 accounted for $57 \%$ of total variability and was mainly associated to carbon source E1, F1. Principal component 2 accounted for only $10 \%$ of total variability and was mainly associated with E4, D1, and G1.

Profiles distribution along principal component 1 was mostly related to community diversity and activity. Slight differences were observed when comparing profiles for bed 


\begin{tabular}{|c|c|c|c|c|}
\hline Biolog EcoPlate & 1 & 2 & 3 & 4 \\
\hline A & Water & $\begin{array}{l}\beta \text {-methyl-D- } \\
\text { glucoside }\end{array}$ & $\begin{array}{l}\text { D-galactonic } \\
\text { acid } \gamma \text {-lactone }\end{array}$ & L-arginine \\
\hline B & $\begin{array}{l}\text { Pyruvic acid } \\
\text { méthyl ester }\end{array}$ & D-xylose & $\begin{array}{l}\text { D-galacturonic } \\
\text { acid }\end{array}$ & L-asparagine \\
\hline C & Tween 40 & i-erythritol & $\begin{array}{l}\text { 2-hydroxy } \\
\text { benzoic acid }\end{array}$ & 1-phenylalanine \\
\hline $\mathrm{D}$ & Tween 80 & D-mannitol & $\begin{array}{l}\text { 4-hydroxy } \\
\text { benzoic acid }\end{array}$ & L-serine \\
\hline E & $\alpha$-cyclodextrin & $\begin{array}{l}\mathrm{N} \text {-acetyl-D- } \\
\text { glucosamine }\end{array}$ & $\begin{array}{c}\gamma \text {-hydroxy butyric } \\
\text { acid }\end{array}$ & L-threonine \\
\hline F & Glycogen & $\begin{array}{c}\text { D-glucosamic } \\
\text { acid }\end{array}$ & Itaconic acid & $\begin{array}{c}\text { Glycyl-L- } \\
\text { glutamic acid }\end{array}$ \\
\hline G & D-cellobiose & $\begin{array}{l}\text { Glucose-1- } \\
\text { phosphate }\end{array}$ & $\begin{array}{c}\alpha \text {-ketobutyric } \\
\text { acid }\end{array}$ & Phenylethyl- \\
\hline $\mathrm{H}$ & $\alpha$-D-lactose & $\begin{array}{l}\text { D, 1- } \alpha \text {-glycerol } \\
\text { phosphate }\end{array}$ & D-malic Acid & Putrescine \\
\hline
\end{tabular}

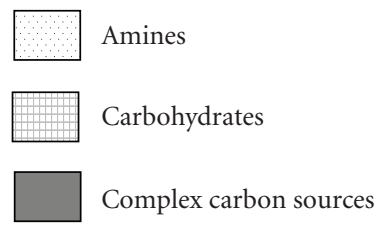

Carboxylic acids

Amino acids

Phosphate-carbon

Figure 4: Carbon sources in Biolog EcoPlate wells. Codification matrix and groups of carbon source isolated (real configuration is in triplicate).

fed and in rest for 3 days in the first stage of Colomieu (1-3 compared to 4-6) (Figure 3). This suggests that the microbial metabolic response is very similar between the two beds and that the growing conditions (amount of nutrients, humidity, etc.) were the same after few days of rest. On the other hand, a net difference appears after 10 days of rest (7-9) (Figure 3), suggesting that microbes were less active and probably less diversified. Whereas carbohydrates and carboxylic acids appeared to be better assimilated with fed beds, it seemed that phosphate compounds as well as amines allowed better growth in the plates inoculated with samples of rest beds [16]. Thus, a change in microbial communities should also appear between fed and long-period rest beds, predicting development of different purifying mechanisms (e.g. endogenous respiration).

Because the second stages were shown to be mostly efficient for TKN removal [15], we expected more differences in microbial communities between stages. A strong difference is only apparent in the deeper profile of the second stage in Colomieu (12) (Figure 3). This difference was also apparent in the ACP of the first campaign (23) (Figure 1). Because Colomieu is the oldest CW, accumulation of organic matter in the deeper zone of the filtration matrix, by generating a reduced environment, could explain its distinct microbial composition. Except for this difference, profiles from Evieu were comparable to those of Colomieu. However, considering principal component 1, Evieu profiles of fed beds were similar to those observed in rest for almost 10 days in Colomieu. This could be a consequence of both the very low organic load in Evieu during the sampling period (Table 1) and the absence of a well-established surface layer. This was shown to enhance biological and hydraulic activities in the oldest CW such as Colomieu $[4,15]$.

One can suppose that wastewater greatly contribute to microbial establishment in CW; it could have been very interesting to compare profiles of influent versus CW effluent to see and study the wetland contribution as showed by Hench et al. [17]. 


\section{Conclusion}

Season was the most important parameter generating variability between bacterial community profiles. Small differences between same samples taken at different depth were observed except for the one of Colomieu $40-60 \mathrm{~cm}$. Profile differences between fed beds and bed in rest for almost 10 days suggest that other degradation mechanisms such as endogenous respiration appeared over time (this could explain low sludge production in French VFCWs). Biolog Ecoplates are a quantitative tool for a simple comparison of microbial metabolic pattern in VFCWs. However care must be taken in interpreting results as the statistical analysis highlights mostly relative differences from a sample profile to another. Furthermore a wide range of bacteria such as strict anaerobic ones are not detected using microplates. Finally, this tool enabled us to see clearly differences between samples taken in the same CW and could be useful to optimize batch loading, to identify dead volumes or bypass, or to estimate dysfunction. In the future, wastewater contribution to bacteria communities should be studied.

\section{References}

[1] S. R. Ragusa, D. McNevin, S. Qasem, and C. Mitchell, "Indicators of biofilm development and activity in constructed wetlands microcosms," Water Research, vol. 38, no. 12, pp. 2865-2873, 2004.

[2] J. D. C. Baptista, T. Donnelly, D. Rayne, and R. J. Davenport, "Microbial mechanisms of carbon removal in subsurface flow wetlands," Water Science and Technology, vol. 48, no. 5, pp. 127-134, 2003.

[3] J. McHenry and A. Werker, "In-situ monitoring of microbial biomass in wetland mesocosms," Water Science and Technology, vol. 51, no. 9, pp. 233-241, 2005.

[4] F. Chazarenc and G. Merlin, "Influence of surface layer on hydrology and biology of gravel bed vertical flow constructed wetlands," Water Science and Technology, vol. 51, no. 9, pp. 9197, 2005.

[5] Ch. Münch, P. Kuschk, and I. Röske, "Root stimulated nitrogen removal: only a local effect or important for water treatment?" Water Science and Technology, vol. 51, no. 9, pp. 185-192, 2005.

[6] C. Criado and E. Bécares, "Characterization of bacterial communities of a constructed wetland in cold conditions," Journal of General and Applied Microbiology, vol. 51, no. 3, pp. 197-201, 2005.

[7] J. L. Garland and A. L. Mills, "Classification and characterization of heterotrophic microbial communities on the basis of patterns of community-level sole-carbon-source utilization," Applied and Environmental Microbiology, vol. 57, no. 8, pp. 2351-2359, 1991.

[8] C. A. Schneider, K. Mo, and S. N. Liss, "Applying phenotypic fingerprinting in the management of wastewater treatment systems," Water Science and Technology, vol. 37, no. 4-5, pp. 461-464, 1998.

[9] S. K. Kaiser, J. B. Guckert, and D. W. Gledhill, "Comparison of activated sludge microbial communities using Biolog ${ }^{\mathrm{TM}}$ microplates," Water Science and Technology, vol. 37, no. 4-5, pp. 57-63, 1998.

[10] D. M. Moll and R. S. Summers, "Assessment of drinking water filter microbial communities using taxonomic and metabolic profiles," Water Science and Technology, vol. 39, no. 7, pp. 8389, 1999.

[11] J. A. Grove, H. Kautola, S. Javadpour, M. Moo-Young, and W. A. Anderson, "Assessment of changes in the microorganism community in a biofilter," Biochemical Engineering Journal, vol. 18, no. 2, pp. 111-114, 2004.

[12] C.-P. Yu and Y.-H. Yu, "Evaluation of biodegradability by the reduction of Tetrazolium Violet in biolog ${ }^{\mathrm{TM}}$ microplates," Biotechnology Letters, vol. 22, no. 11, pp. 909-913, 2000.

[13] Biolog, June 2006, http://www.biolog.com/pdf/eco_microplate _sell_sheet.pdf.

[14] J. B. Guckert, G. J. Carr, T. D. Johnson, B. G. Hamm, D. H. Davidson, and Y. Kumagai, "Community analysis by Biolog: curve integration for statistical analysis of activated sludge microbial habitats," Journal of Microbiological Methods, vol. 27, no. 2-3, pp. 183-197, 1996.

[15] P. Molle, A. Lienard, C. Boutin, G. Merlin, and A. Iwema, "How to treat raw sewage with constructed wetlands: an overview of the French systems," Water Science and Technology, vol. 51, no. 9, pp. 11-21, 2005.

[16] F. Chazarenc, Optimisation des systèmes de traitement des eaux usées domestiques par filtres plantés de macrophytes, Ph.D. thesis, Universite de Savoie, France, 2003.

[17] K. R. Hench, A. J. Sexstone, and G. K. Bissonnette, "Heterotrophic community-level physiological profiles of domestic wastewater following treatment by small constructed subsurface flow wetlands," Water Environment Research, vol. 76, no. 5, pp. 468-473, 2004. 

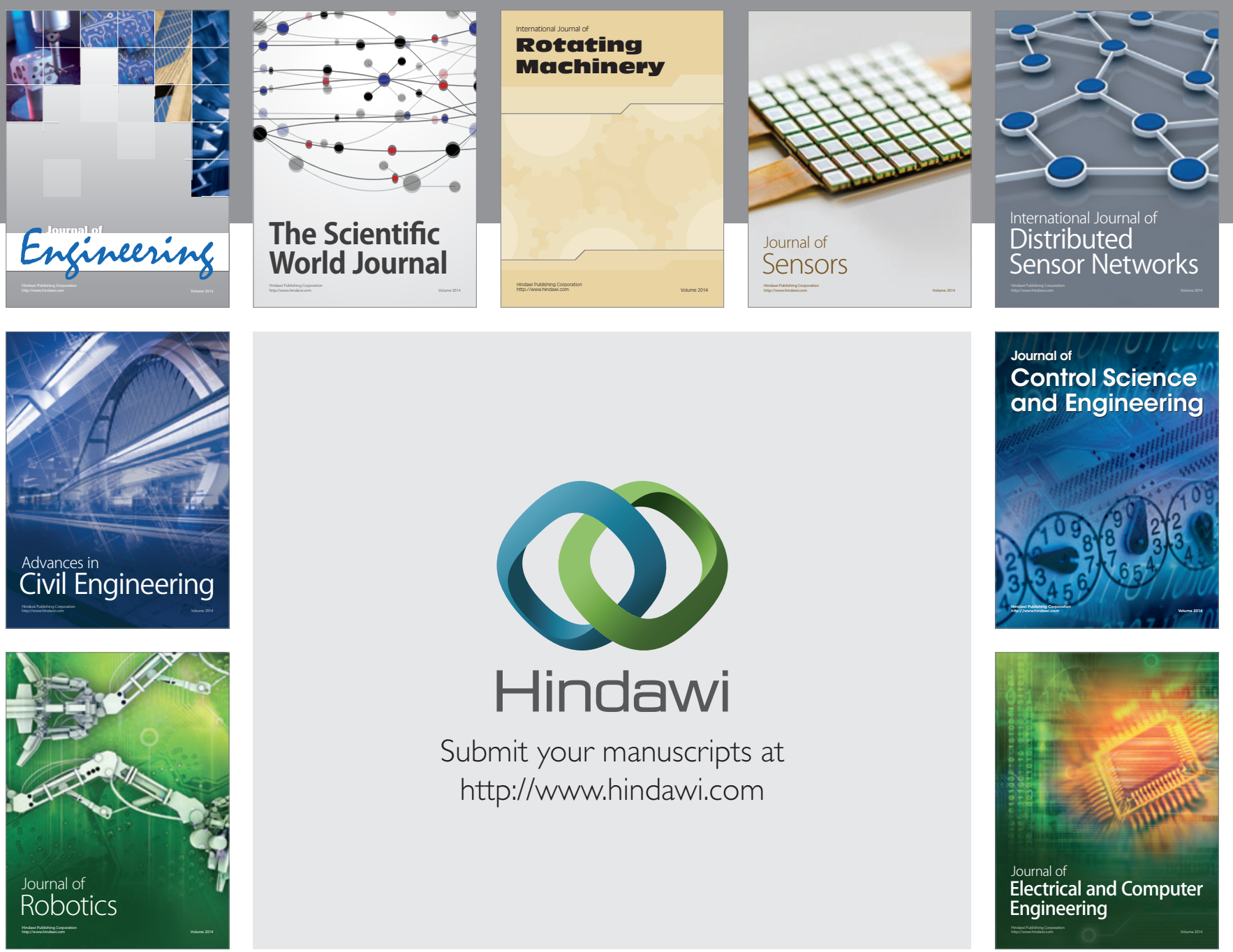

Submit your manuscripts at

http://www.hindawi.com
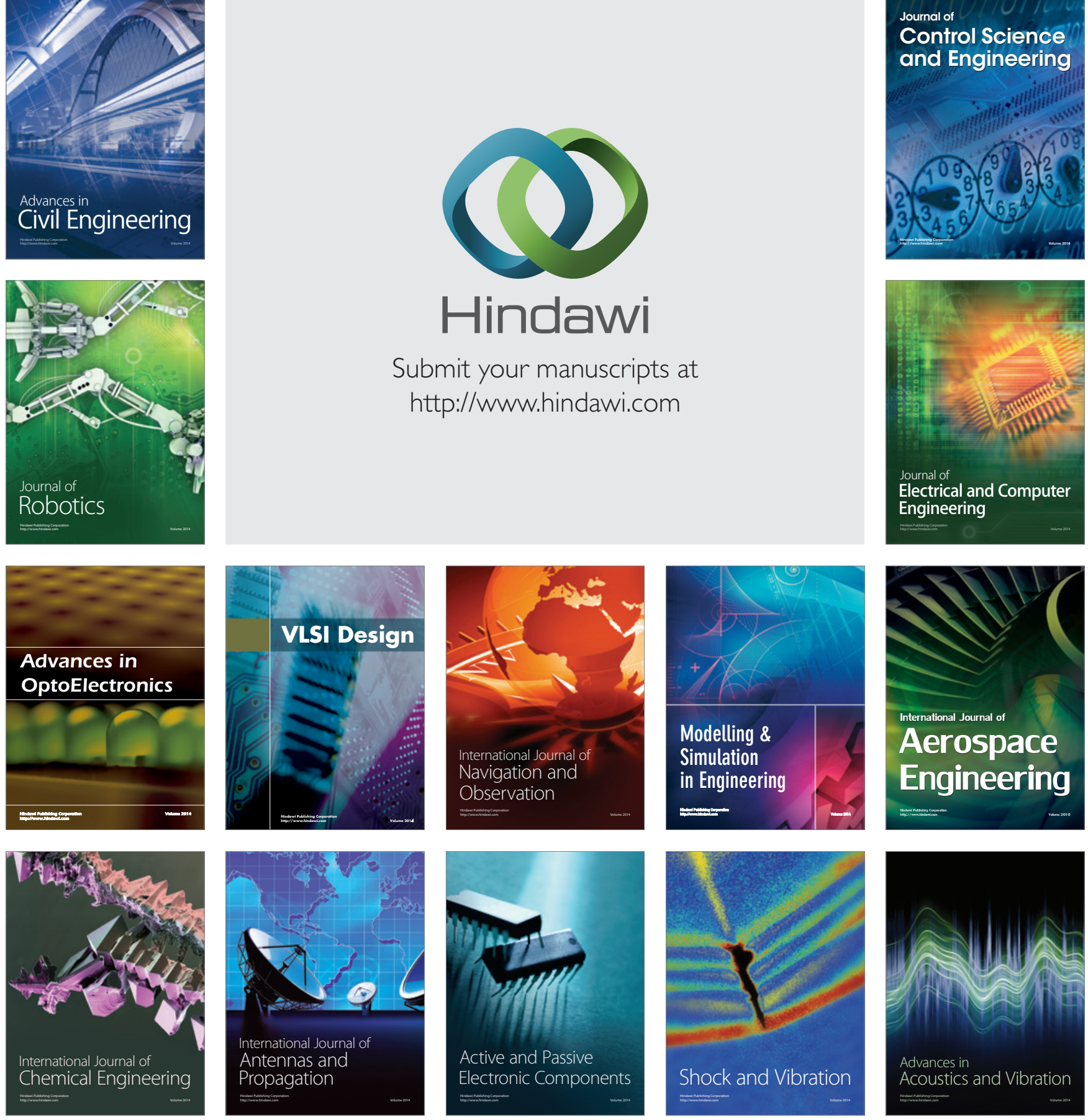